\title{
INNER-CITY TRANSFORMATION BETWEEN REURBANIZATION AND GENTRIFICATION: LEIPZIG, EASTERN GERMANY
}

\begin{abstract}
HAASE, A., RINK, D. (2015): Inner-city transformation between reurbanization and gentrification: Leipzig, eastern Germany. Geografie, 120, No. 2, pp. 226-250. After the beginning of the post-socialist transformation, the eastern German city of Leipzig underwent various changes within a short time span. These changes have been especially dynamic in its inner city. Whereas it was hit by the loss of large parts of its population and increasing housing vacancies in the $1990 \mathrm{~s}$, the 2000 s brought about a revitalization and new attractiveness of many inner-city districts. Since then, reurbanization and - in some places - gentrification have become the predominant trends in a rising number of inner-city districts. This development has also reshaped patterns of socio-spatial differentiation in the city as a whole and its inner parts. Set against this background, the paper describes the development of Leipzig's inner city after 1990. The focus of the paper is it to show how various concepts - reurbanization and gentrification - help to explain this development. Of particular interest thereby is the impact of Leipzig's specific housing market situation that is characterized by long-term experiences of supply surplus and shrinkage.

KEY WORDS: inner-city transformation - reurbanization - gentrification - housing oversupply - Leipzig - eastern Germany.
\end{abstract}

\section{Introduction: \\ Inner-city transformation in eastern Germany}

To subsume the eastern German developments into the post-socialist framework is by no means an easy endeavor. On the one hand, eastern Germany, or the former GDR, represents a post-socialist region or former state socialist country. It has undergone, on the other hand, a very specific process of postsocialist transformation, due to its immediate integration into western German and European Union structures after 1990, which meant a fundamental change of the political, legal, and institutional structures without any adaptation. Through this development, the East German economy was confronted with international or even global competition "overnight", which resulted in massive deindustrialization. Simultaneously, eastern Germany was integrated into the institutions and legislative structures of the western German welfare system. Subsequently, the post-socialist transformation of eastern German cities was characterized by economic crisis, functional losses, but also by institutional stabilization and welfare system development. Similar to eastern European countries, the transformation was seen as a kind of catch-up modernization, but, in contrast to the other post-socialist cases, for eastern Germany, the aim 
of catching-up was very clear, because the western German model was seen as the blueprint for any modernization process. Based on the assumption of an imagined "hour zero", as after the Second World War, it was expected that eastern German cities would again be "integrated into the German urban hierarchy, where they have been excluded after 1945" (Henckel et al., 1993, p. 79). Accordingly, soon after the political reunification, eastern German inner cities were expected to develop, according to patterns that were known from western German cities: “... de-mixing in the large housing estates ... upgrading (gentrification) of the inner-city neighborhoods ... increasing overall segregation..." (Friedrichs, Kahl 1991, p. 182). Some years later, these assumptions were even tightened; Jürgen Friedrichs, a western German urban sociologist, spoke about "urban development in fast forward motion": "The development in the cities of the GDR does not follow the phases in the FRG but jumps over phases and starts suddenly with today's phase of development of FRG's cities." (Friedrichs 1995, p. 57) In the mentioned assumption, it was consequently ignored that the eastern German cities had undergone a 40-year development as state socialist cities, which also impacted considerably on their inner-city development.

Leipzig, in addition, represents an interesting case, because it was one of the largest and most developed German cities before the Second World War. Leipzig was, after 1945, subsumed under the paradigm of state socialist development but it was not a so-called "socialist model city", such as Schwedt, Eisenhüttenstadt, or Halle-Neustadt. Its city center and inner-city areas were, thus, less impacted by state socialist developments than other cities. From the 1960s onwards, the city was, instead, characterized by disinvestment and neglect, environmental devastation and decay, which led to continuous shrinkage over decades, up till the end of the GDR. As a consequence, the crisis of state socialism was particularly pronounced as an urban crisis in Leipzig and formed one of the reasons for the famous Monday demonstrations that heralded the political turnaround in 1989.

Set against this background, the paper describes the development of Leipzig's inner city after 1990. The focus of the paper is it to show how various concepts - reurbanization and gentrification - help to explain this development. Of particular interest thereby is the impact of Leipzig's specific housing market condition, which was characterized by long-term experiences of supply surplus and shrinkage.

The paper refers to Leipzig as a post-socialist city because it looks back on a 40-year period of state socialism, from 1949-1989. The legacy of this period is still impacting on Leipzig's current development, although a fundamental restructuring of almost all urban structures and policy fields in the city has occurred. Compared with other post-socialist cities, Leipzig - like all East German cities - represents an exception because of the consequences of German reunification. However, just because of this fact, it represents an interesting case for post-socialist studies that aim at demonstrating how post-socialist urban development functioned under the conditions of both rapid and fundamental change and rapid and comprehensive integration into new structures. 


\section{Leipzig's inner-city transformation in the light of two theories: gentrification and reurbanization}

Leipzig's inner-city transformation after 1990 has undergone several changes and shows multiple facets. On the one hand, the inner city was affected by those processes that occurred at the overall city level (e.g., massive out-migration during the $1990 \mathrm{~s}$, moderate in-migration during the $2000 \mathrm{~s}$, and dynamic inmigration at present). On the other hand, inner-city transformation has never been a monolithic or uniform process; it includes different, small-scale developments that are close to each other and occur simultaneously.

Leipzig's development has been impacted on by two factors, or drivers, that are specific: firstly, the post-socialist condition that led to abrupt and fundamental changes in, e.g., the local economy, population development, and the housing market situation and, secondly, as a result of these changes, the emergence of housing oversupply and vacancies, which, in turn, created specific conditions for residential mobility, housing market development, and socio-spatial differentiation.

In terms of a scientific analysis, one can start from two different points either, one looks at Leipzig's inner-city transformation through the lens of a certain concept (e.g. gentrification or reurbanization), or one discusses empirical evidence in the light of differing concepts, in order to understand the on-going transformation in a comprehensive and context-aware way that also includes certain aspects that cannot be explained well or sufficiently by just one concept. For this paper, we have chosen the second approach, not least because we consider that the developments cannot be understood without a consideration of the overall context of housing oversupply and post-socialist conditions. Therefore, in this section, we first briefly explain in which way the two concepts of reurbanization and gentrification are fruitful for helping us to explain Leipzig's inner-city transformation, before we turn to the case study and empirical evidence. We cannot provide a full and detailed review of the two concepts, which we already elaborated (separately) for the eastern German and as well as Leipzig's context in earlier papers (Haase et al. 2010; Bernt, Rink, Holm 2010). For this paper, we focus only on those aspects that are necessary to show why we find these two concepts relevant for our case and endeavor.

Gentrification and reurbanization represent two distinct approaches for explaining inner-city transformation. The term Gentrification was created by Ruth Glass in 1964 to describe a critical concept for analyzing urban change and has a 50-year-old discourse history. Gentrification is defined here as the transformation of a working-class or vacant area of a city for middle-class residential and/or commercial uses (Marcuse 1986). The physical upgrading of the built structures and the increase in housing costs lead to the displacement of the residential population. After 1990, urban research also applied the concept to eastern Germany and the anticipated gentrification of East German cities, either in a form similar to that which had occurred in the western part of the country or, due to the post-socialist transformation, even in an accelerated form (Friedrichs, Kahl 1991). However, due to deindustrialization and shrinkage, urban development in eastern Germany differed from previously established 
western patterns and, thus, scholars adopted the term "split gentrification" (referring to physical upgrading without gentrifiers; see Harth, Herlyn, Scheller 1998). During the 2000s, gentrification has rarely been an issue, because of the high levels of housing vacancies and oversupply. Instead, the concept of reurbanization was introduced, to address the repopulation of the inner-city neighborhoods, a process that was much wanted and, thus, also supported by urban policymakers. Gentrification only played a role as an accompanying "soft" factor, representing a process of social upgrading without displacement (Wiest, Hill 2004). Since the beginning of the 2010s, gentrification has become an important issue of development and debate in several East German cities, particularly in Leipzig; here, dynamic in-migration has increasingly led to upgrading and displacement (Rink 2015). Up to the present, there is a discussion if and how both processes, reurbanization and gentrification, are related to each other and whether gentrification follows reurbanization or is its indispensable companion.

The second concept, reurbanization, was introduced to explain inner-city change. For this paper, we understand reurbanization, "... at the level of the entire city, as a process of relative or absolute population increase in the city, in comparison with its suburban zone and hinterland. At the neighbourhood level, it is understood as a revival of the residential function of the inner city after a longer phase of decline by becoming populated and diversified by a variety of residential groups of different ages and socio-economic backgrounds." (Haase et al. 2012, p. 1177) Reurbanization, as it is defined here, conceptualizes urban change as the nexus of interrelations between demographic transformations and the changes in residential neighborhoods in terms of their housing stock, amenities, and socio-economic structures. It is applied to cases where these interrelations support a consolidation of the residential function of inner-city districts, always set against a previous phase of decline or shrinkage. Its added explanatory value lies in bringing the realms of urban development, i.e., developments related to an area, and its built-environment, and socio-demographic transformations under a common conceptual umbrella.

Leipzig today (spring 2015) is one of the most prominent examples of regrowth after a phase of decline in eastern Germany (Rink et al. 2012; Heinig, Herfert 2012). Bernt (2009, pp. 75, 83) sees Leipzig as a "comeback city"; Power, Ploeger, Winkler (2011) characterized Leipzig as a "Phoenix city". As for the regional context, there are scholars who even declare reurbanization to be the "mainstream" of urban development of large East German cities during the 2000s (Wiest 2005), a development that becomes increasingly visible also in terms of total population development, especially inner-city population growth, throughout recent years. Leipzig thus stands for a broader regional trend.

Reurbanization and gentrification (as they are understood here) follow different explanatory pathways. Whereas a gentrification perspective looks critically at the questions of social segregation, class, residential upgrading, and, primarily, displacement, the reurbanization perspective focuses on the character and impact of residential change on inner-city areas, in terms of their residential function, attractiveness, and sustainable use over the medium to long term (Haase et al. 2010). Therefore, we plead for a clear distinction between the two processes with respect to the terminological and conceptual framework and, at 
the same time, for an acknowledgement that the two phenomena are processes that are currently under way.

With respect to scholarly debates on inner-city transformation and Leipzig's specific context (post-socialist, housing oversupply), we have to consider two further issues in more detail:

Firstly, many studies on inner-city development have in common that housing shortage always provides the background for the developed heuristics. Most studies on gentrification have dealt with revitalizing/revitalized neighborhoods in housing markets with high demand, which makes such inner-city neighborhoods places of selective upgrading. Even reurbanization studies often report on cities that are changing but not shrinking, despite the fact that the concept considers urban areas after a phase of decline, there are only a few exceptions that report specifically on reurbanization set against former shrinkage (Couch, Fowles, Karecha 2009; Rink et al. 2012). Housing oversupply, as a driver of inner-city transformation, is, to date, either inadequately, or even virtually not considered. Although there is an emerging consideration of oversupply as a determining factor for housing markets (e.g., Gabriel 2001; Spieker 2005; Fielder, Smith 1996; Keenan, Lowe, Spencer 1999), it is absent in the debate on neighborhood development or socio-spatial differentiation. As we will show for the case of Leipzig, however, it has had a decisive impact on changes over the last two decades.

Secondly, there is a relatively new debate that discusses the specifics of uneven distribution of social groups across the urban space under the conditions of the post-socialist transition. New social inequalities have appeared, but existing empirical studies agree that the socio-spatial restructuring of post-socialist (inner) cities is path-dependent and does not lead to the same patterns of socio-spatial differentiation as in western Europe (Marcinczak, Musterd, Stepniak 2011; Kährik 2002; Ruoppila 2006; Steinführer 2004; Parysek 2005). Although increasing segregation could not be measured, especially in the $1990 \mathrm{~s}$, it has been reported that new "socio-spatial formations" (Sýkora 2009) have emerged, often showing very small-scale patterns or, as Marcinczak and Sagan (2010, p. 1789) express it for the example of Łódź, Poland, a "finegrained fragmentation of social space". Scholars have applied and challenged the concepts of reurbanization and gentrification that are based on western expertise and were developed with western evidence (Standl, Krupickaite 2004; Sýkora 2009; Haase, Grossmann, Steinführer 2012; Bernt, Rink, Holm 2010). Among others, studies on inner-city transformation reported that: "In the central locations, the continuous absence of clear regulations on property restitution, coupled with the vast preservation of socialist-era tenure rights, moderated the pace of gentrification, leading to piecemeal residential and social upgrading and, consequently, further sociospatial fragmentation." (Marcinczak et al. 2013, p. 344) But, in this debate, the context of housing markets characterized by oversupply is also absent - simply because oversupply does not play a role in most other post-socialist cities; evolving vacancies and demolitions of housing are mostly related to the poor technical state of these buildings; in most cases, they are no longer inhabitable and do not form part of the housing market anymore (see Bierzyński et al. 2011, among others, for the case of Łódź). 
Set against this background, our paper pinpoints a case in which inner-city development is characterized by housing oversupply and rapid transformation. How does inner-city transformation come about here? Do processes follow logics similar to those found in contexts of growth or demand surplus? How much explanatory power do the concepts of reurbanization and gentrification have in such contexts? How do they help to understand inner-city transformation under these conditions? The paper also thus contributes to the debate on methodological questions by critically examining the explanatory power of different concepts, and how they interact, for understanding multi-layered developments over time.

\section{The Leipzig context: between shrinkage, regrowth and housing supply shifts}

Leipzig is, historically, a city of trade and commerce. Since the mid- $19^{\text {th }}$ century, the city has experienced dynamic industrialization and urbanization, resulting in a previously unknown level of population growth. The city reached its maximum population in 1933, with 713,470 inhabitants (Fig. 1). During the Nazi era, the population decreased by more than 100,000; even though the city was a destination for returnees and refugees after the war, until the beginning of the $1950 \mathrm{~s}$, the population only increased by around 40,000. Shrinkage occurred again: During the 1950s, many young and well-qualified people left for the western part of Germany, as long as the border was still open. This decline ended with the erection of the Berlin Wall in 1961. Afterwards, until the mid-1960s, in- and out-migration were almost balanced, and high birth rates even brought

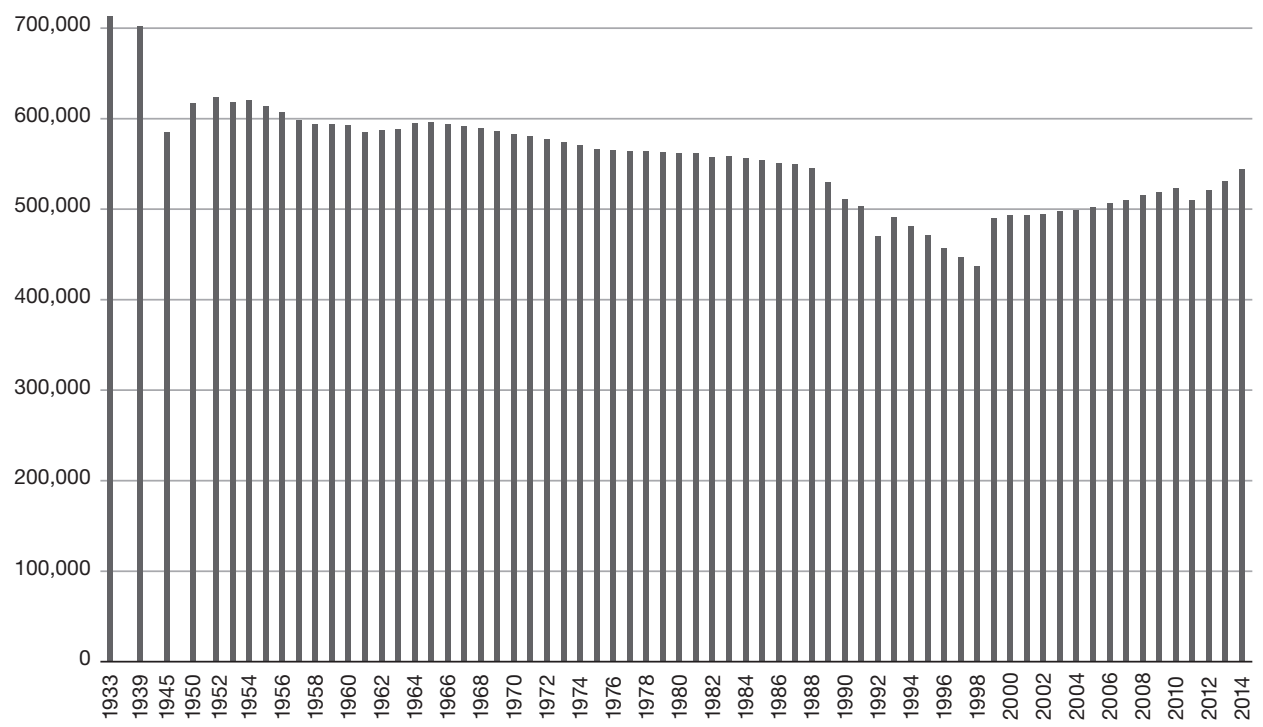

Fig. 1 - Leipzig's population development 1933-2012.

Source: Statistical Office of the City of Leipzig. 


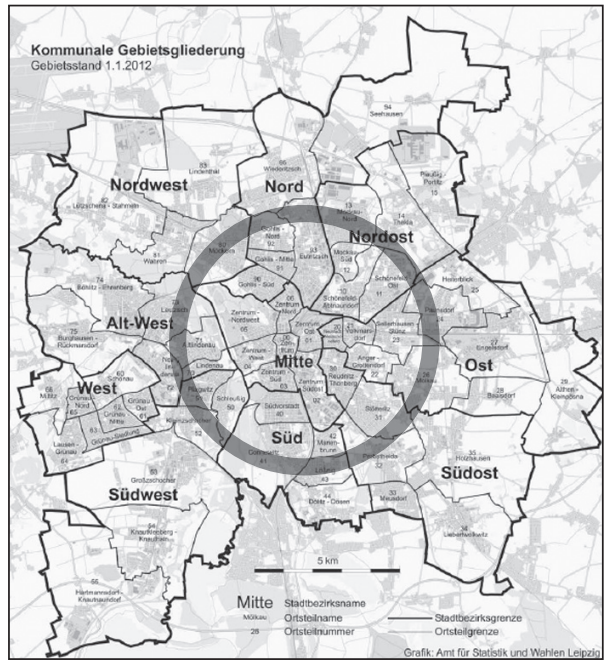

Fig. 2 - Delimitation of Leipzig's inner city. Source: City of Leipzig, authors' additions. an interim first phase of re-growth. The years between this interim high and the political changes in 1989 were characterized by only gradual population decline. In this phase, Leipzig's industries and economy declined. Large parts of the inner city decayed because the old building stock was systematically neglected by investment and renovation, in favor of new housing estates that were built from the 1960s onwards at the periphery. Some of the typical impacts of urban shrinkage, such as housing vacancies and decay, worn-out technical infrastructures and selective migration, which altered the socio-demographic structures of the city, became increasingly visible. At the end of the $1980 \mathrm{~s}$, planners even drafted the scenario of

a "dying city" for Leipzig: 70-80 per cent of the old built up stock in the inner city was planned for demolition. Thus, the famous Monday demonstrations and the revolution of 1989 were also a "break-out" from this urban crisis, which was perceived as worse than at the end of the Second World War: "Today, the city faces, all in all, a more desolate situation than at the end of the Second World War because, over four decades, the basic needs of long-term maintenance of values had been neglected." (Topfstedt 1990, p. 27)

This history of an early and rapid urbanization marks an important difference to many eastern European cities that had not experienced growth and urbanization before the socialist period after 1945. With its aborted development into a European metropolis and its long-term shrinkage, Leipzig represents an extreme case of socialist and European urban development. Apart from shrinkage, Leipzig also represents a prominent example of (economic and population) regrowth after shrinkage, a "comeback city" or "Phoenix city", as mentioned above.

When speaking about Leipzig's inner city, we refer to those inner-city residential districts that form the "first ring" around the city center and are predominantly characterized by Wilhelminian building stock. This area includes about 25 districts, out of 63, and currently has about 150,000 inhabitants (out of 550,000, for the entire city, in 2014). The analyzed inner-city area includes different types of districts, among them residential districts with higher, middle and lower status, as well as mixed residential and industrial areas. The city center itself remains out of sight because of its multi-functionality and its lower importance as a residential area (Fig. 2).

In the following sections, we will analyze the development of Leipzig's inner city, focusing on the relationship between the contexts of oversupply and housing market development, residential development, as well as socio-spatial differentiation, starting with the 1990s and ending in the 2010s. Subsequently, 
we discuss how the concepts of reurbanization and gentrification help us to understand this development and what follows from it for further empirical and theoretical debates.

\section{The 1990s: shrinkage and regeneration}

After the political turnaround in 1989, Leipzig underwent the most extreme phase of its long period of population loss. By 1998, the city had lost a further 100,000 inhabitants. Immediately after the opening of the wall, thousands migrated to western Germany; in November and December 1989 alone, 14,000 people left the city, followed in 1990 by a further 16,000 . With the transformation induced by German reunification and the integration into the European Union, the city experienced a change in practically all spheres of urban development. The most serious change was the unparalleled deindustrialization within just a few years, during which 85 per cent of industrial jobs in the city were lost. Altogether, 100,000 jobs were lost, decreasing Leipzig's job-base by a third. The unemployment rate rose from near zero to above 20 per cent in the mid-1990s and early 2000s (Rink et al. 2011). This had a twofold impact on the population development: Firstly, it led to large-scale out-migration to western Germany; secondly, it caused an extreme breakdown in birth rates. The fertility rate dropped to a previously unknown level. In 1995, a total fertility rate of 0.77 children per woman was recorded in eastern Germany, which corresponded the world's lowest value (Federal Statistical Office Germany 2003). As a consequence, during the first half of the 1990s, 20,000 more people died in Leipzig than were born there. In the second half of the 1990s, a massive and publicly subsidized suburbanization process started that additionally increased population losses. Suburbanization played an

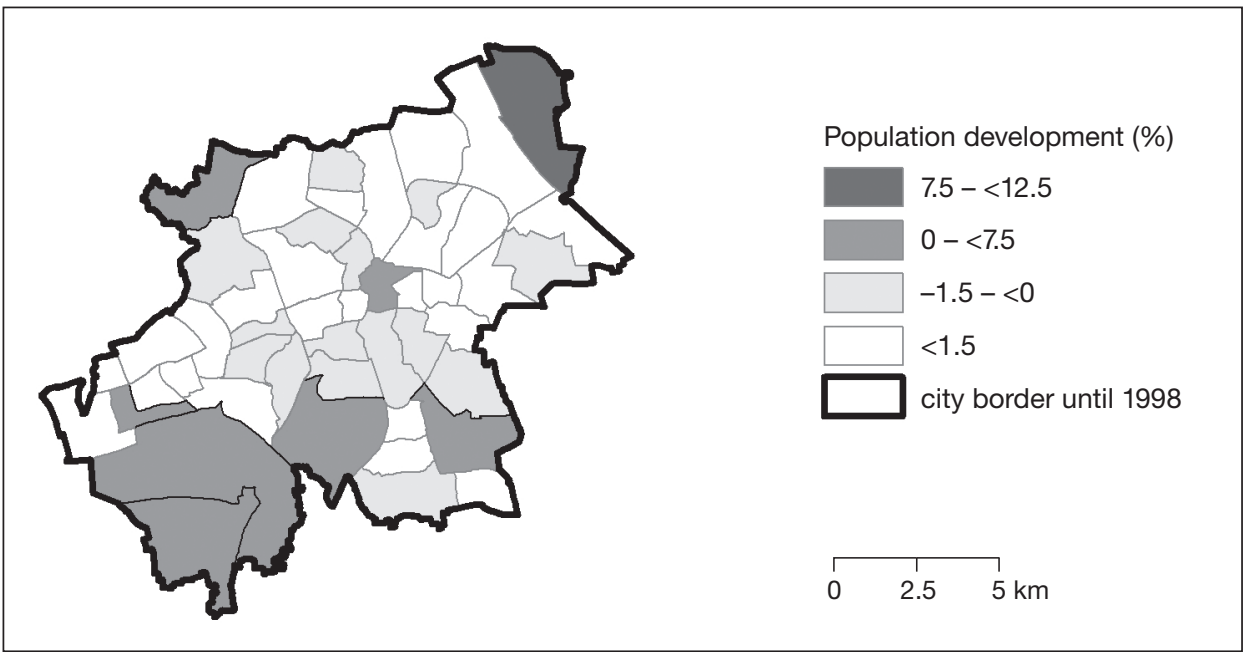

Fig. 3 - Population change in Leipzig 1992-1998 in \% according to districts.

Source: Statistical office of the City of Leipzig. 


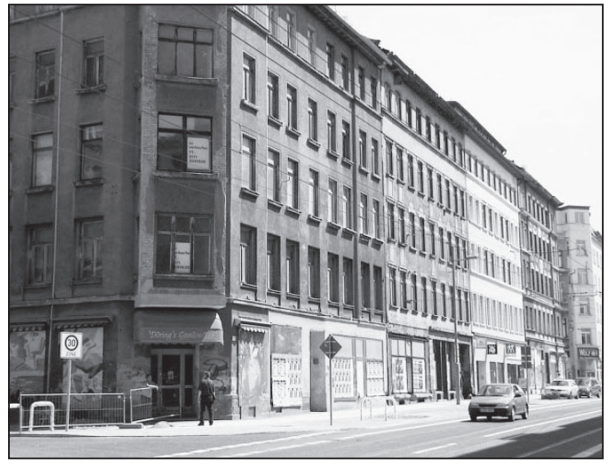

Fig. 4 - Dilapidating inner-city housing stock. Photo: A. Haase. important role in the out-migration of many families, because they could not find an appropriate place to live within the borders of the city - thus, even those who did not really want to live there fled to suburbia (Herfert, Röhl 2001). The main period of suburbanization was brief; it lasted from 1994 to 1997 and almost 30,000 people left Leipzig for its surrounding areas (Nuissl, Rink, 2005). The decline affected almost all parts of the city but the inner city as a whole (Figures 3 and 4). The losses were especially high in the inner city and, there, in the least attractive districts with dilapidated housing and poor living conditions. Despite this rather grim picture of crisis and shrinkage, Leipzig's development at the beginning of the 1990s was accompanied by euphoria, and became manifest with the image of the "boomtown of Germany's east" (Heinkers, 2004). Set against the background of deindustrialization, the city formulated the model of a service metropolis of European importance. By 2000, it was explicitly envisaged that the city would grow to as many as 500,000 inhabitants (Döhler, Rink 1996, p. 265). Because of its initial role during the peaceful revolution in 1989 , the city became a symbol of German reunification and reconstruction in the 1990 s.

After years of neglect and disinvestment, the city administration prioritized urban regeneration and restructuring. In order to overcome the city's legacy from the socialist era - decay, vacancies, and housing shortage - housing renewal was promoted as a central issue of municipal policy. For this purpose, 13 large renewal areas with a total area of 600 hectares were targeted, in order to mobilize private capital. Together with public subsidies and tax reductions, more than 2 billion Euros were invested in the housing market alone during the 1990 s. In effect, the city was able to overcome housing shortages and refurbish large parts of the historical stock as well of the large housing estates. At the end of the 1990s, it was estimated that approximately two thirds of the historical building stock - a large part of the inner city - was refurbished, although the scope and speed of renovations varied greatly between the districts. Unfortunately, both the renewal in the inner city and the construction boom in the suburban zone were completely contrary to the described population trends. As a consequence, the increasing disparity between the growing supply on the housing market and a decreasing demand resulted in soaring vacancy levels. In the second half of the 1990s, oversupply increased rapidly, while ongoing outmigration decreased the demand further. At the same time, the housing market was liberated; all the regulations of the socialist legacy were abolished. The vacancy rate peaked in 2000, with 69,000 empty flats, approximately 20 per cent of the total housing stock. In other words, the city had a clear vacancy crisis. Thus, housing vacancies - or oversupply - became the major problem associated with urban shrinkage and led to a shift of municipal policy and urban 
planning. The lack of occupancy led to a variety of consequences: a general devaluation of vacant sites, lower housing prices, and a loss of mortgage value. In addition, a boom in residential mobility occurred, with relocation rates nearly twice as high as in other German cities. This was fostered by rapidly growing choice options and the simultaneous reduction of barriers for relocations, especially in terms of costs. As a result, both the housing market and the residential population were thoroughly reshuffled. During this phase, the emergence and reconfiguration of new patterns of residential segregation were observed (Grossmann et al. 2014). Firstly, the inner city started to rejuvenate, while outer districts grew older, in terms of residents' average age. Secondly, concentrations of foreigners formed in selected inner-city districts. Thirdly, unemployed residents concentrated in the eastern and western former workers' areas and in the large housing estates on Leipzig's periphery. Thus, pre-war patterns of socio-spatial differentiation were partially reinstated, also in some old, more affluent, built-up areas in the inner city. Thus, these new patterns demonstrated, in part, a path-dependency with respect to pre-1945 structures. Especially in the 1990s, both population losses and vacancies correlated strongly with socio-demographic indicators. Even though other post-socialist cities have also experienced such a newly emerging segregation (e.g., Sýkora 2009, for Prague), the scope and dynamics that we observed in Leipzig are rarely found elsewhere. In many inner-city districts, large parts of the population were "exchanged" by massive out-migration in the 1990s and new in-migration in the 2000s; the levels of residential mobility exceed by far the levels that can be found in western German, but also in other large post-socialist cities. This represents the true specifics of the East German situation, and it shows, very clearly, the "nexus" between the processes of post-socialist transformation and shrinkage/oversupply. Because of this situation, Leipzig was called the "capital of housing vacancy" around 2000.

In summary, Leipzig's inner city experienced, during the $1990 \mathrm{~s}$, a fundamental change in just one decade. The socialist past of the city provided a specific starting point for the transition, with its pronounced physical dilapidation of the old building stock and related vacant (because uninhabitable) flats (a stock of around 15,000 units in 1989). In this context, there were cases of gentrification caused by both direct and exclusionary displacement. In fact, physical upgrading of the most valuable parts of the old built-up inner city did occur, because of speculation about higher prices and rents (Wiest, Hill 2004). However, due to oversupply that also included many recently refurbished vacant buildings, prices fell, even during the phase of extensive renovations. Subsequently, gentrification was not able to really develop and remained somehow "split", as Harth, Herlyn, and Scheller (1998) described it. This means that only physical renewal and upgrading, but not social upgrading, occurred. At the time, Leipzig saw massive out-migration, due to job losses and the suburbanization of those who could afford to build their own house; consequently, there was virtually a complete lack of potential gentrifiers who could (and also would) have paid higher rents for inner-city housing. 


\section{The 2000s: reurbanization and restructuring}

Leipzig's long phase of population decline came to an end by the late 1990s and the city started, firstly, to stabilize and, then, to regrow. Even though the ambitious development goals in the years immediately after 1989 were not met, vast public and private investments contributed to an overall upgrading of the city. The core of the growth-oriented policy was to encourage strong investors to settle in the industrial and service sectors. Another focus of strategic planning in Leipzig was the attraction of large events: it participated in the EXPO 2000, it was the German applicant city for the Olympic Games in 2012; it co-hosted the Soccer World Cup in 2006, and will apply to become a European cultural capital. The city has become an important location for vocational and higher education, a cultural center, and a place known for high quality but inexpensive living. Furthermore, it has become a transport hub, with a newly built airport, good train connections, and good access to national highways. Apart from these investments, Leipzig has also been able to profit substantially from European programs such as EFRE, URBAN II or Objective One. As a result of substantial investments, and with the new economic growth, the situation on the labor market has changed: In the second half of the 2000 s, the unemployment rate was significantly reduced and the number of jobs increased substantially.

Set against this background, population numbers initially increased, as a result of a municipal authority reform in 1999, which expanded the city boundaries to include some of the former suburban areas. As a result, some of the suburbanites who had left the city in the 1990s were formally "regained" as

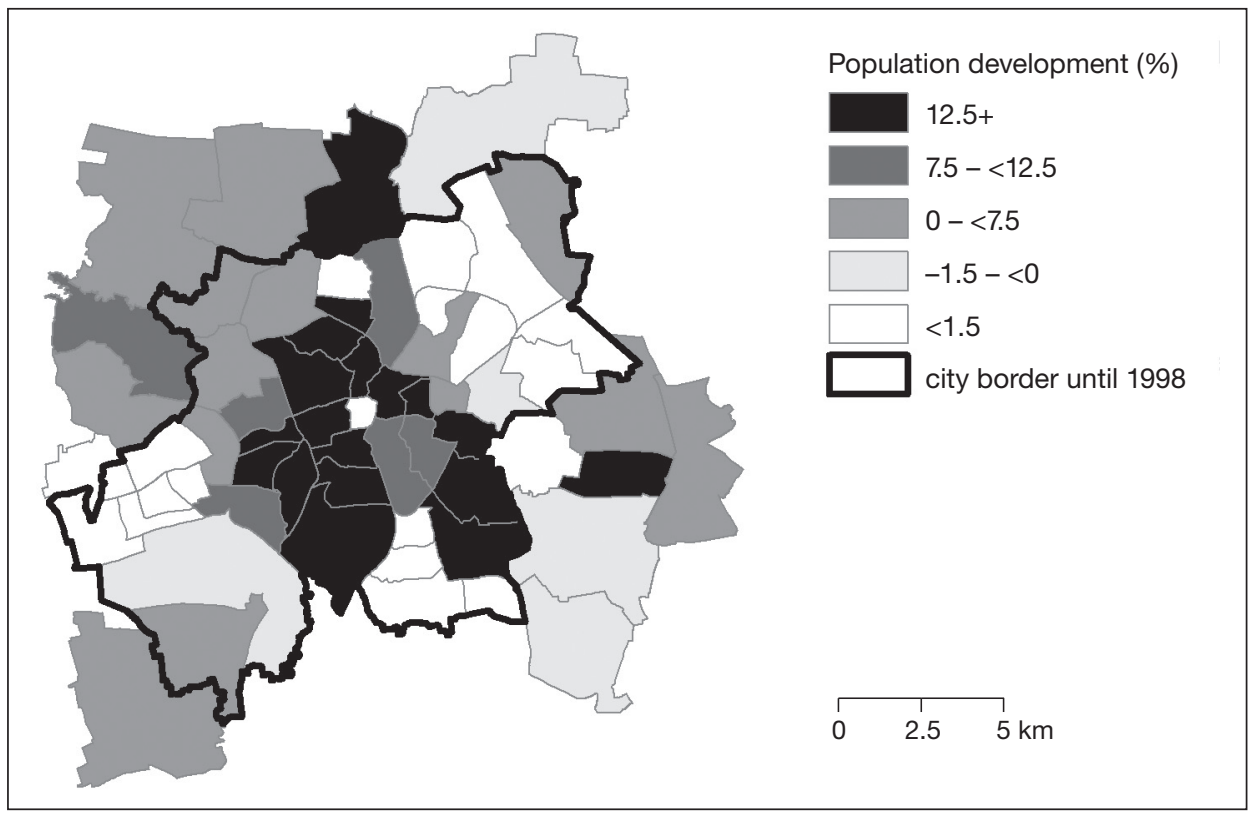

Fig. 5 - Population change in Leipzig 1999-2009 in \% according to districts. Source: Statistical office of the City of Leipzig. 
inhabitants by the city. However, the statistical effect of this territorial enlargement plays a relatively marginal role in the explanation of the reurbanization in the 2000s. The major issue behind the population growth is related to inmigration, primarily from Saxony and the other eastern German federal states. The main carriers of reurbanization were younger migrants aged 18-30; most of them relocated to the inner city (Fig. 5). In-migration thus includes mainly students, apprentices, and early-stage professionals. The number of students has nearly doubled, from about 18,000 in 1990 to about 37,000 in the 2010s. Whereas in-migration has become more dynamic, during the $2000 \mathrm{~s}$, drivers of population decline have lost their impact. Suburbanization has come to a halt and the previously dynamically growing outskirts are now losing population to the city. As a result, Leipzig has moved into a phase of reurbanization characterized by regaining population in the city - particularly the inner-city - and stagnation, even population loss, in the hinterland.

These shifting migration trends have been accompanied by a decline in the natural population loss. Here, yearly death rates are increasing, but so are birth rates. Overall, the rate of natural decline is decreasing, because birth rates in Leipzig have slowly increased during recent years.

The current re-growth has impacted differently on different districts (Fig. 5). The influx is feeding the reurbanization of the inner-city districts, which are experiencing rejuvenation (Fig. 6 shows this process by means of the share of the 20-30-year-olds from 1992 to 2011) and a diversification of their sociodemographic structure. The proportion of the population under 40 years old is increasing with the arrival of so-called "new" household types, such as young,

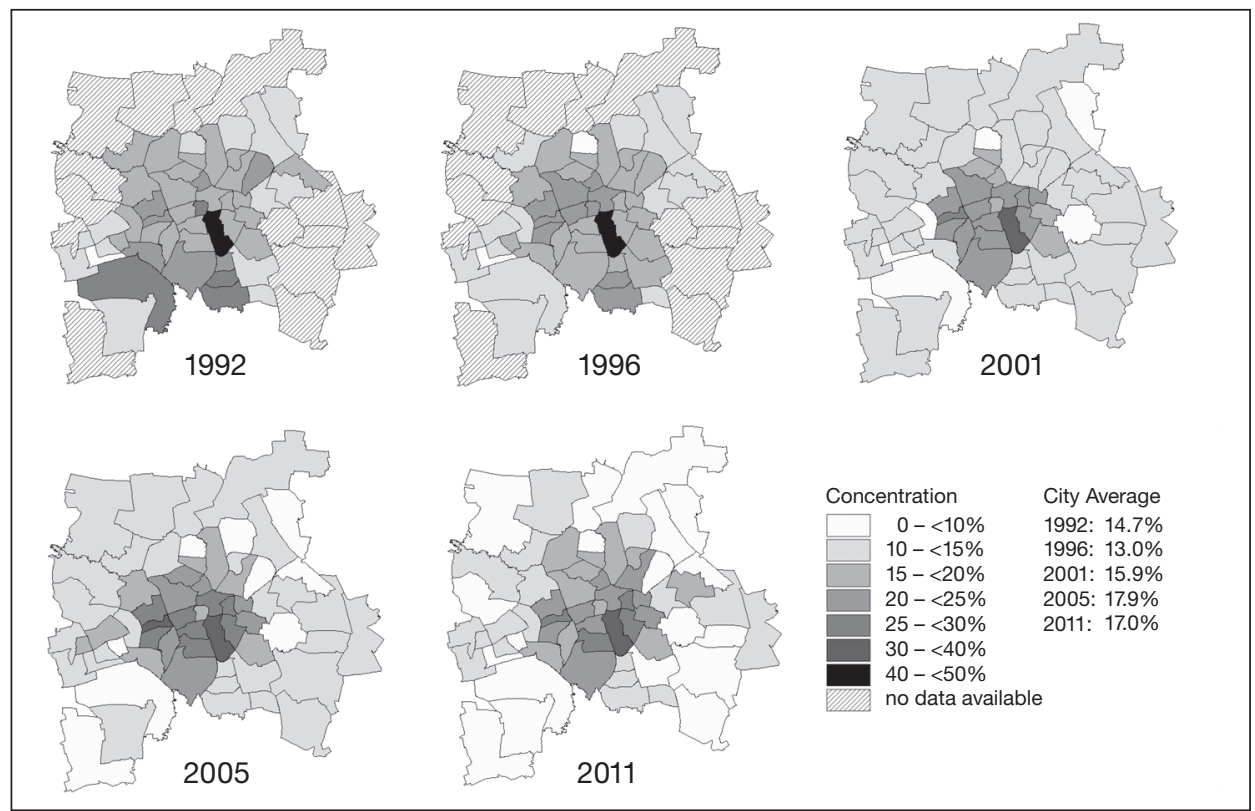

Fig. 6 - Concentration of 20-30-year-olds in Leipzig according to districts 1992-2011. Maps: T. Arndt. 
single-person households, cohabitating young couples, and flat sharers. According to municipal data, these inner-city districts are, moreover, characterized by the smallest mean household sizes (below 1.75, which represents the mean value for the city, see Stadt Leipzig 2013) and lower mean age (4-8 years lower than the city average, see Stadt Leipzig 2012), compared to the total city values. Furthermore, families with dependent children and single-parent families have also moved in; in some districts of Leipzig's inner East, many of them are migrant families (Steinführer, Haase, Kabisch 2009; Haase et al. 2012). Reurbanization has not only contributed to population exchange and rejuvenation but also to new forms of mix in the residential population and, in some areas, to a significant importance of transitory housing (Steinführer, Haase 2009). The socio-economic background of reurbanites includes a variety of income groups, educational and professional groups - a considerable share represents low-income households or households in a precarious income situation. Reurbanizing inner-city districts has followed several pathways: while some areas are becoming migrant areas, others are upgrading, with elements of gentrification or even family gentrification; still others are developing into mixed areas with a large share of transitory housing; many districts, however, have still a mixed population with respect to age, educational background, and income.

The basis of reurbanization in Leipzig has been an attractive housing market with a large number of newly renovated, available, and affordable housing units in practically all inner-city locations. Leipzig's housing markets at the beginning of the new century had some features in common with today's housing markets struggling with real estate bubbles resulting in low prices and oversupply in all segments and locations. Admittedly, this was the background for political responses from the federal government, inspired by the threat of bankruptcy of municipal and cooperative housing companies. On the basis of a federal program for urban restructuring (Stadtumbau Ost), an integrative master plan was developed and implemented in 2002. During the 2000s and until the end of the program in 2014, all in all 14,000 flats were demolished, mostly in large housing estates built in the state socialist period in outer parts of the city. At the same time, upgrading in the inner city was supported with the help of several instruments and measures: low-density housing (e.g., town houses), renaturation of brownfields, and renovation of vacant housing. By end of the 2000s, the large majority of pre-1918 building stock in the inner city, approximately 85 per cent, was renovated. Due to in-migration and its concentration in the inner city, vacancy rates started to decline after 2000 and more than halved to around 23,000 units in 2014; forecasts predict a further decline in vacancy rates, due to expected in-migration (Stadt Leipzig 2013).

The reurbanization of the inner city has not necessarily led to social upgrading and exclusion. First and foremost, it has stabilized and strengthened its residential function and has led to a decrease in housing vacancies, at least in the more attractive districts. In the less attractive areas, in-migration has helped to slow the rate of net out-migration. Gentrification appeared in a specific form because exclusion was rarely observed. Therefore, the change of socio-spatial structures is assessed as "soft" gentrification (Wiest, Hill 2004; Heinig, Herfert 2012). 


\section{The 2010s: dynamic in-migration and gentrification}

Reurbanization has continued from 2010 up till the present (2014); in addition, population growth has become more dynamic and now covers more or less the entire city. Starting with 2011, about 10,000 people have migrated to Leipzig each year. In other words, this corresponds to approx. $2 \%$ annual population growth. This rate is comparable to the population growth rate that was typical for the time around the transition from the $19^{\text {th }}$ to the $20^{\text {th }}$ century, i.e., the time of industrialization and urbanization. Recently, even the migration balance, compared with western Germany, seems to have changed direction. In 2010, for the first time since German reunification, Leipzig had a positive migration balance with western German federal states $(6,281$ inmigrants vs. 5,822 out-migrants, cf. Stadt Leipzig, 2011, p. 2). The prognosis for the future development has become even more optimistic; some observers and local politicians are expecting growth to reach 600,000 inhabitants until 2022. This growth is also fed by improvements in the economy and the employment situation. For instance, the number of unemployed more than halved, from 21 per cent in 2005 to 9 per cent in 2014, and the number of jobs grew by around 40,000 within the same period. In general terms, in-migrants and immigrants to the inner city, in the main younger households, including singles, flat sharers, and cohabitees, but also families with dependent children and single parents, have pushed reurbanization and rejuvenation forward in the respective districts, from the end of the 1990s onwards. Figure 7 shows that the trend of young in-migration to Leipzig's inner city, as described for the 2000 s,

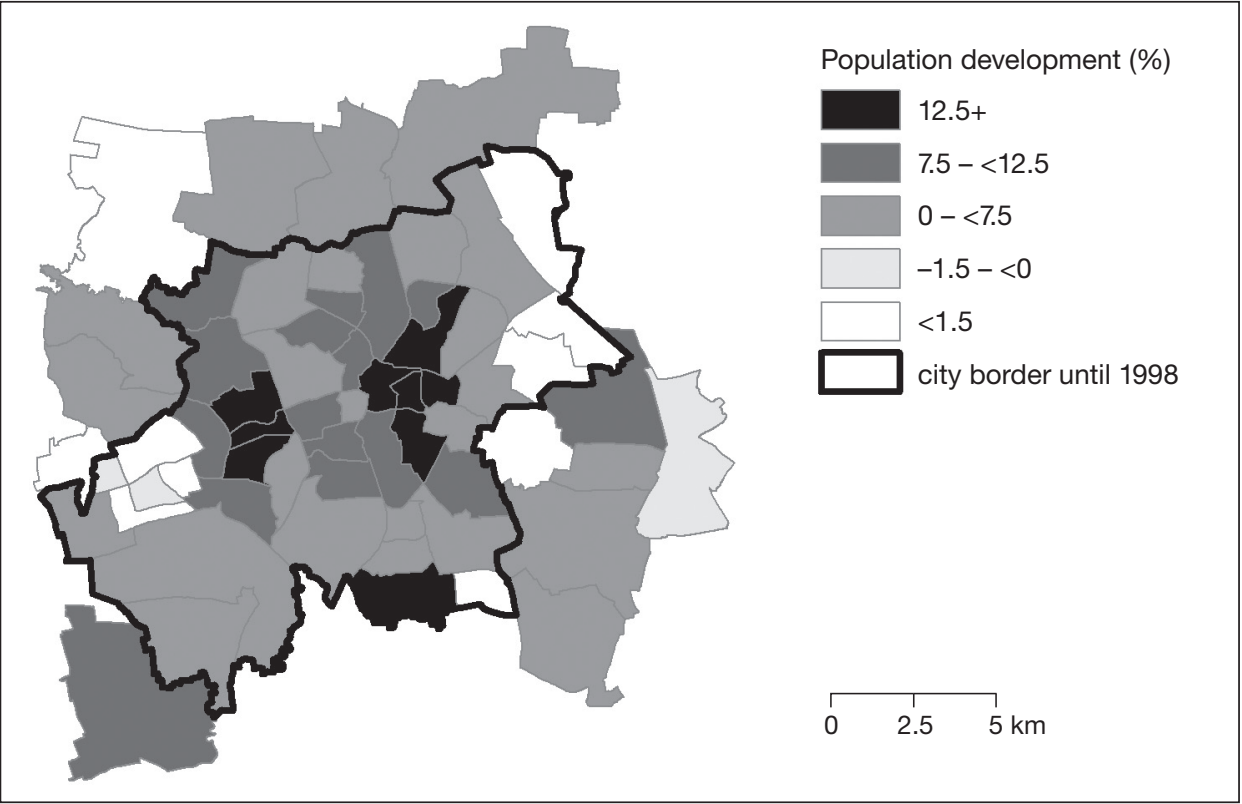

Fig. 7 - Population change in Leipzig 2009-2013 in \% according to districts.

Source: Statistical office of the City of Leipzig. 


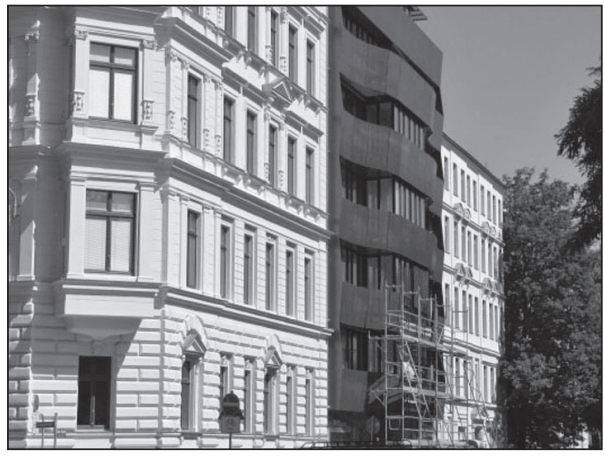

Fig. 8 - Upper market housing. Photo: D. Rink.

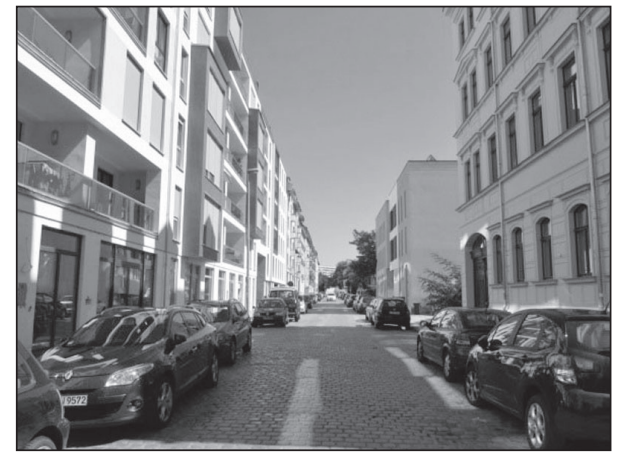

Fig. 9 - New multistory construction. Photo: D. Rink.

continued after 2009, gathered momentum and now encompasses the complete inner city. Although mostly younger, these groups display a diverse composition of age groups, education, and income levels (Haase et al. 2010). Among the reurbanites, there was also a group of people who could be called pioneers (of future or symbolic upgrading), but this was only a restricted segment of all the reurbanites and not the majority.

Recent population growth has increased demands on the housing market and has resulted in a new phase of renewal and even new construction in the inner city. While renovation activities concentrate on the remaining unrefurbished stock (Fig. 8), at the same time, a new segment has been created: new construction of upper-market housing (Fig. 9) that is concentrated in inner-city locations, often close to Leipzig's floodplain forest area, which crosses the city's territory from south to northwest (Fig. 10). In addition, new neighborhoods for more than 10,000 inhabitants are planned on former brownfield sites in central and more peripheral locations of the inner city; the new offers are directed at the demand for middle class housing. These developments have impacted on the housing market, leading to

- decreasing shares of vacancy in the inner city although, according to the 2011 census, vacancy shares are still the highest in some districts in which old-built up stock predominates; nevertheless, it is expected that vacancies will, in the near future, decrease in the inner city and reach the so-called "natural" vacancy or fluctuation rate of a balanced housing market (4-5 per cent)

- rising real estate property prices and rents with a consistently more pronounced pattern of differentiation, first and foremost between attractive inner-city areas that see a demand surplus and less attractive inner-city areas as well as areas at the periphery that continuously experience supply surplus.

With these developments, the low-price segment has become smaller, whereas the high-price segment has increased and, most probably, will continue to grow in the future. Whether new, affordable housing will be available is, however, completely uncertain. 


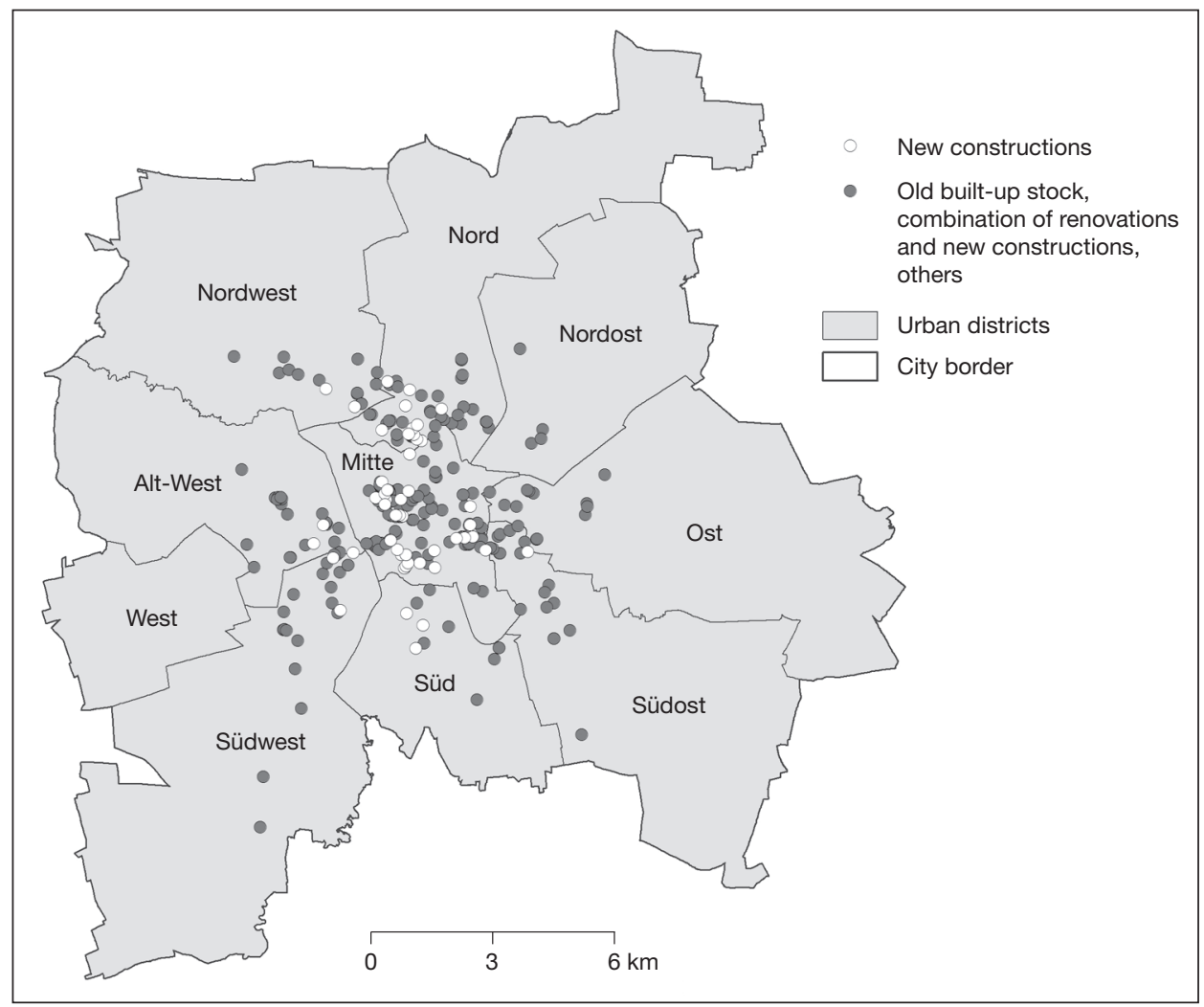

Fig. 10 - Locations of upper price segment housing in Leipzig: renovation and new buildings. Data: A. Schneider, GIS and Mapping: B. Lier, H. Kirschner. Last update: 1 July 2014.

As a result, it seems that, currently, reurbanization has spread to large parts of the inner city and does not only occur in selected neighborhoods and that gentrification processes have become more visible and pronounced. In former working-class districts in the Western inner city, gentrification is resulting predominantly from both upscale renovations and new construction; it is also present, but to a lesser extent, in other parts of the inner city. This development has led to an increase of both existing and new rental contracts. Whereas, in the 2000 s, gentrification was assessed as being "soft" and without direct displacement, the situation in the 2010s has changed fundamentally. Now, one can observe "ordinary" or "typical" gentrification (i.e., not "split", "soft", etc.) in parts of the inner city. Because, during the 2000s, renewal occurred mainly in vacant and decaying buildings that were not inhabited, its consequence is direct exclusion, to a lesser extent and, more often, exclusionary displacement (according to Marcuse 1986). In the 2010s, by contrast, several dozens of houses in the inner city have become examples of direct displacement. The western part of the inner city was most "hit" by this development; here, "islands of gentrification" (Bernt, Rink, Holm 2010) now constitute an "archipelago". Due to ongoing massive investment in both upgrading and new construction, 
the social make-up of the whole district is changing in a way that is typical for "classical" gentrification. From 2010-2014, 1,400 housing units in discrete neighborhoods of the western part of the inner city were upgraded to the upper price segment by renovation or by new construction, representing, altogether, some 7 per cent of the total housing stock. Additionally, within this area, some 3,000 housing units are currently under construction or renovation, or waiting to be built. Gentrification has become, in other words, a deliberate strategy to develop the most attractive parts of the inner city that are most in demand. Other parts of the inner city are affected to a lesser extent by upgrading; the rates range from 1-5 per cent. Because of the high housing demand, vacant housing is increasingly disappearing from the inner city, which creates housing shortages in distinct segments and locations. In addition, the specific character of Leipzig's gentrification story is due to the high poverty level of the city. As a result of deindustrialization and massive job losses during the 1990s, Leipzig has been, up to the present, a poor city with a large share of low-income households (25 per cent) and a relatively low average income (1,066 Euro in $2011^{1}$ ). In the 2010 s, Leipzig was on the top of the list of large German cities with high proportions of households below the poverty line (Der Paritätische Gesamtverband 2015) and was repeatedly called the "capital of poverty" in Germany by the media ${ }^{2}$. Because of increasing rents and the transformation of rental into private housing, poor households are forced to migrate to the remaining low-price housing, particularly to prefab housing estates in the peripheral areas of the city (Rink 2015).

What has become obvious is that the newly emerged patterns of socio-spatial differentiation, as they developed in the second half of the $1990 \mathrm{~s}$, have not only consolidated but have also become more pronounced. It has also become clear that, through the increasing level of investment and the scope of regrowth, it will be increasingly difficult for the municipality to steer the housing market. This is, not least, due to the fact that the municipal housing company has been under pressure from austerity measures and has privatized a large segment of its stock, most of which is located within the inner city, partly to global investors. Consequently, developments in the housing market have touched not only the field of housing policy but also the field of urban governance as a whole.

\section{Revisiting the concepts: How do they help to explain Leipzig's inner-city transformation?}

To return to to the questions posed at the beginning of the paper:

How has inner-city transformation in Leipzig developed up to the present? Which processes and conditions have impacted on its pathway?

As the empirical part of the paper has demonstrated, Leipzig's inner city has undergone several phases of transformation since 1990. The duration of

1 http://www.lvz-online.de/leipzig/citynews/leipzigs-bestverdiener-wohnen-im-waldstrassenviertel-einkommen-in-volkmarsdorf-am-niedrigsten/r-citynews-a-148560.html

2 http://www.spiegel.de/wirtschaft/soziales/grosser-vergleich-leipzig-ist-deutschlands-armutshauptstadt-a-703787.html 
Table 1 - Phases of inner-city development

\begin{tabular}{|c|c|c|}
\hline Phase & Key processes & Developments in the inner city \\
\hline $1990 \mathrm{~s}$ & $\begin{array}{l}\text { Deindustrialization } \\
\text { and crisis, shrinkage, } \\
\text { emerging oversupply, } \\
\text { gentrification (I) }\end{array}$ & $\begin{array}{l}\text { massive outmigration, simultaneous renovation } \\
\text { through massive public and publicly subsidized } \\
\text { private investments: both processes caused turn from } \\
\text { housing shortage to oversupply, "split" gentrification, } \\
\text { first signs of reurbanization (migrants and } \\
\text { students), reconfiguration of patterns of socio-spatial } \\
\text { differentiation }\end{array}$ \\
\hline $2000 \mathrm{~s}$ & $\begin{array}{l}\text { Reindustrialization } \\
\text { and economic upswing, } \\
\text { reurbanization, peak } \\
\text { and decrease in } \\
\text { oversupply }\end{array}$ & $\begin{array}{l}\text { moderate in-migration, inner-city reurbanization/ } \\
\text { rejuvenation, urban restructuring of the inner } \\
\text { city (upgrading of built stock and public space, } \\
\text { demolitions) by public investments vs. private } \\
\text { disinvestment, decrease in oversupply (halved), } \\
\text { consolidation of patterns of socio-spatial } \\
\text { differentiation }\end{array}$ \\
\hline $2010 \mathrm{~s}$ & $\begin{array}{l}\text { Boom, reurbanization, } \\
\text { gentrification (II), } \\
\text { decrease in oversupply, } \\
\text { conflicts, fragmentation }\end{array}$ & $\begin{array}{l}\text { dynamic in-migration, further decrease in oversupply, } \\
\text { (physical) upgrading (new constructions, renewal) } \\
\text { driven by private investments with gentrification } \\
\text { (direct and exclusionary displacement) }\end{array}$ \\
\hline
\end{tabular}

Source: Authors' compilation

the individual phases or the dynamics of change were determined by the local context and supralocal conditions. At the local level, population losses and gains on the demand side of the housing market, as well as changes on the supply side (renewal, modernization, construction, demolition) belong to the most important drivers of transformation. At the supralocal level, processes such as the post-socialist condition, the extension of the West German welfare state and the integration of Leipzig into European structures, as well as global economic and real estate structures and their interplay are crucial for understanding the scope, speed, and characteristics of inner-city transformation.

To typify the development in Leipzig, we divided the two and a half decades that we investigated into three phases (see Table 1).

In the first phase, the 1990s, shrinkage was the predominant development in Leipzig's inner city (and the city as a whole, as well). At the same time, large parts of the inner city's old built-up stock were renovated, by publicly subsidized private investments. As a consequence, the housing market experienced a shift from shortage towards oversupply. These two processes - prevailing shrinkage and increasing oversupply - determined socio-spatial processes in the inner city. High residential mobility (out-migration and relocation within the city's territory) led to the emergence of new patterns of socio-spatial differentiation in the second half of the 1990s. At the end of the 1990s, the first signs of reurbanization became visible. Rare cases of gentrification did not receive much attention, mostly because there was always more renovated vacant housing available and relocations were frequent and possible for relatively large segments of the population.

The second phase, the 2000s, was mainly characterized by reurbanization both at the overall and inner-city level. Reurbanization in the 2000 s meant, 
first and foremost, a stabilization of the residential function of many inner-city neighborhoods that had suffered from enormous population losses until the late 1990s. Reurbanization took place in front of the backdrop of restructuring, i.e., demolition of over-supply housing, and the absence of private investments. Reurbanization brought about rejuvenation and a diversification in household types and social groups. The pathways of reurbanizing inner-city districts are very varied; gentrification is one of them but it only appeared in some of the districts. Because of considerable oversupply and moderate rents, displacement was still not a substantial problem, although some of the areas undergoing gentrification showed clear signs of exclusionary displacement. Other reurbanizing inner-city districts have developed into migrant areas, neighborhoods of transitory housing, family districts, or - not least - have remained mixed areas but show another type of mix after the "exchange". Those patterns of socio-spatial differentiation that had developed in the second half of the 1990s became consolidated.

In recent years, the 2010s, we see a continuation of the processes described for the second phase. The character of reurbanization progressed from representing a stabilization of inner-city districts, after a phase of decline, to processes of population growth, redensification and new construction in more and more parts of the inner city. One can observe a new cycle of investments, mainly privately funded. Even if one cannot yet speak of a large-scale gentrification, and the predominant process is still reurbanization, in some areas, reurbanization paved the way for gentrification. In contrast to the 1990s, cases of gentrification receive more public attention and have led to conflicts because the context has changed (Rink 2015). Even though many inner-city areas in Leipzig are still mixed, they are becoming increasingly less accessible for low-income groups. This trend is alarming. Generally, Leipzig's inner city has seen increasing fragmentation in recent years - we can find upgrading and renewal next to dilapidation, redensification adjacent to vacancies.

How much explanatory power do reurbanization and gentrification have in such contexts? How do they help to understand inner-city transformation under those conditions?

Table 1 reveals a close relationship between migration directions, oversupply development, and socio-spatial development in larger or smaller parts of the inner city. On the one hand, Leipzig's context of oversupply was important for the fact that gentrification was not an issue for a long time.

In contrast to earlier assumptions, the inner city as a whole had not undergone gentrification up to the moment when this paper was written. Here, Leipzig is in line with developments in eastern Germany, as a whole, where gentrification did not apply to a large extent; one can find only "islands of gentrification in a sea of shrinkage" (Bernt, Rink, Holm 2010, p. 199). The analyzed developments can also be compared to research on other post-socialist cities pointing to the fragmentary or micro-scale way of the concentration of wealthier groups in inner-city locations (see e.g., Marcinczak, Sagan 2010; Marcinczak et al. 2013). Moreover, Leipzig continues to be a poor city with a large share of low-income households (see above). Despite the described developments in some areas in recent years, there is no large-scale potential for gentrification until today. 
Who - under the conditions that we find in Leipzig - are the gentrifiers? Do we possibly have to adjust definitions (Bernt, Rink, Holm 2010, Table 2)? There is also a pronounced sensitivity about low-rate increases in housing costs, because the threshold that has to be exceeded to exclude many households from more expensive housing market segments is relatively low.

Reurbanization in Leipzig was, in some cases, a "door-opener" for gentrification, mainly in recent years. Our research confirms that gentrification in Leipzig can be interpreted - according to Brake and Urbanczyk (2012, p. 42) - as a "typical consequence of reurbanization", insofar as it represents one of the pathways that are followed by reurbanizing inner-city districts or certain segments of the housing market at different locations across the inner city. Nevertheless, it is just one of several pathways, as we have stated above. Reurbanization, in contrast to gentrification, thus represents a process that is distinctive by nature but partly driven by similar dynamics. We do not share Holm's conclusion (2012, p. 249) that gentrification has become a systematic concomitant of reurbanization. As we have shown, there are parts of Leipzig's inner city that are still mixed or migrant neighborhoods.

As far as the explanatory power of the two concepts is concerned, we can conclude that both gentrification and reurbanization are relevant concepts for grasping dimensions of Leipzig's inner-city transformation, but one concept alone cannot fully explain what has happened. However, evidence shows that they play well together as an explanatory approach for larger-scale and smallerscale processes. We need both of them, and it is important that terms are used precisely and appropriately to maximize their explanatory value. It seems to be crucial to identify which conditions or criteria determine the scope, speed, and direction of both reurbanization and gentrification. As we could show, both gentrification and reurbanization explain other aspects of transformation; thus, while reurbanization is relevant for describing Leipzig's regrowth period, gentrification helps to explain why we see conflicts and displacement.

\section{Conclusion}

Gentrification and reurbanization are, in our view, two concepts that are qualitatively distinct. They do not have a simple temporal or causal relationship, as our analysis has demonstrated. Gentrification is not the logical consequence of reurbanization; it does not necessarily or inescapably follow reurbanization. In the case of Leipzig, we have shown that its specific story of the interplay between reurbanization and gentrification is much due to its context of shrinkage and housing oversupply. In the 1990s, gentrification was solely driven by supply in a time of massive population loss and remained "split" because of a lack in demand. In the 2000 s, the city experienced vibrant inner-city reurbanization through various residential groups and, within this framework, the character of gentrification remained "soft", due to housing oversupply and the absence of displacement. Subsequently, these decades cannot be interpreted as a double invasion/succession cycle. Just within the last years of dynamic regrowth, one can observe processes of gentrification comparable to the well-known cyclic models. The differences between the phases can be explained, first, by changing 
relationships between supply and demand on the housing market and, second, by different investment cycles, based on their source, form, and extent.

Leipzig is, thus, a meaningful example of a non-classical development of gentrification. In addition, it shows that an explanatory approach that draws on more than one concept can help to provide a comprehensive picture and reveal how different developments are interlinked and interact. It also shows that contextual factors are crucial for understanding how processes such as reurbanization and gentrification emerge, proceed, and change over time, as well as understanding which factors are driving and changing them.

Due to its specifics, Leipzig is only directly comparable in a limited way to other post-socialist contexts, as well as to western contexts. This is because of its specific development in the post-socialist era, not because of shrinkage and oversupply as such, since these can also be observed in other cities; the combination of the two contexts led to this exceptional development. Despite its specifics, the analysis of Leipzig's inner-city transformation can offer relevant knowledge for other contexts in a wider sense: it may serve as an example of what happens when oversupply emerges and tell about how it impacts on housing market and residential developments, and: which risks and chances might be related to it. The case of Leipzig also illustrates which consequences housing oversupply may have for socio-spatial processes. Due to the various expressions of current demographic change, mainly ageing and increased and diversifying (international) migration, there will be many cities across Europe and worldwide that will see a development that oscillates between growth, shrinkage, and re-growth. Leipzig represents a meaningful example for the multiple consequences that such a development may have at different places and in different segments of a local housing market, as well as how it (positively and negatively) affects various residential groups. Not least, the current real estate breakdowns in some European countries within the course of the fiscal crisis (Spain, Ireland, Greece, Slovenia, etc.) have led to housing oversupply that will have an impact on local housing markets in the affected cities and, possibly, also on residential mobility and socio-spatial differentiation. Leipzig's experience might also be of use in such situations. Last but not least, the paper concludes with a pledge to consider concepts such as gentrification and reurbanization with respect to their interlinkages and interaction. Leipzig's specifics may inform the general debate by challenging existing interpretational frames of inner-city change through processes of repopulation and residential change.

\section{References:}

BERNT, M. (2009): Partnerships for demolition: the governance of urban renewal in East Germany's shrinking cities. International Journal of Urban Regional Research, 33, pp. 754-769.

BERNT, M., RINK, D., HOLM, A. (2010): Gentrificationforschung in Ostdeutschland: konzeptionelle Probleme und Forschungslücken. Berichte zur deutschen Landeskunde, 84, No. 2, pp. 185-203.

BIERZYŃSKI, A., GRABKOWSKA, M., HAASE, A., KLUSÁČEK, P., MAAS, A., MAIR, J., MARTINÁT, S., SAGAN, I., STEINFÜHRER, A., VAISHAR, A., WĘEAWOWICZ, 
G., ZAPLETALOVÁ, J. (2011): Łódź, Gdańsk, Brno and Ostrava and their inner cities: Urban and demographic development during post-socialism. In: Haase, A., Steinführer, A., Kabisch, S., Grossmann, K., Hall, R. (eds.): Residential change and demographic challenge. The inner city of East Central Europe in the $21^{\text {st }}$ century. Ashgate, Farnham, Burlington, pp. 101-140.

BRAKE, K., URBANCZYK, R. (2012): Reurbanisierung - Strukturierung einer begrifflichen Vielfalt. In: Brake, K., Herfert, G. (eds.): Reurbanisierung. VS Verlag, Wiesbaden, pp. 34-51.

COUCH, C., FOWLES, S., KARECHA, J. (2009): Reurbanization and housing markets in the central and inner urban areas of Liverpool. Planning Practice and Research, 24, pp. 321-341.

Der Paritätische Gesamtverband (2015): Die zerklüftete Republik. Berichte zur regionalen Armutsentwicklung in Deutschland 2014, Berlin, http://www.der-paritaetische.de/armutsbericht/die-zerklueftete-republik/ (16. 3. 2015).

DÖHLER, M., RINK, D. (1996): Stadtentwicklung in Leipzig: Zwischen Verfall und Deindustrialisierung, Sanierung und tertiären Großprojekten. In: Häussermann, H., Neef, R. (eds.): Stadtentwicklung in Ostdeutschland. Soziale und räumliche Tendenzen. Springer VS, Opladen, pp. 263-286.

FIELDER, S., SMITH, R.(1996): Vacant dwellings in the private sector. HMSO, London, $70 \mathrm{pp}$.

FRIEDRICHS, J. (1995): Stadtsoziologie. Leske + Budrich, Opladen, 182 pp.

FRIEDRICHS, J., KAHL, A. (1991): Strukturwandel in der ehemaligen DDR - Konsequenzen für den Städtebau. Archiv für Kommunalwissenschaften, 1, pp. 169-197.

GABRIEL, S.A. (2001): Rental housing markets, the incidence and duration of vacancy, and the natural vacancy rate. Journal of Urban Economics, 49, pp. 121-149.

GROSSMANN, K., HAASE, A., ARNDT, T., CORTESE, C., RUMPEL, P., RINK, D., SLACH, O., TICHA, I., VIOLANTE, A. (2014): How urban shrinkage impacts on patterns of sociospatial segregation: The cases of Leipzig, Ostrava, and Genoa. In: Yeakey, C.C., Thompson, V.S., Wells, A. (eds.): Urban ills: Post recession complexities to urban living in global contexts. Lexington Books, New York, London, Boston, Volume 1, s. 241-267.

HAASE, A., KABISCH, S., STEINFÜHRER, A., BOUZAROVSKI, S., HALL, R., OGDEN, P. (2010): Emergent spaces of reurbanisation: Exploring the demographic dimension of inner-city residential change in a European setting. Population, Space and Place 16, No. 5, pp. 443-463.

HAASE, A., HERFERT, G., KABISCH, S., STEINFÜHRER, A. (2012): Reurbanizing Leipzig (Germany): Context conditions and residential actors (2000-2007). European Planning Studies 20, No. 7, pp. 1173-1196.

HAASE, A., GROSSMANN, K., STEINFÜHRER, A. (2012): Transitory urbanites: New actors of residential change in Polish and Czech inner cities. Cities, 29, pp. 318-326.

HARTH, A., HERLYN, U., SCHELLER, G. (1998): Segregation in ostdeutschen Großstädten. Eine empirische Studie. Leske + Budrich, Opladen, 280 pp.

HEINIG, S., HERFERT, G. (2012): Leipzig - intraregionale und innerstädtische Reurbanisierungspfade. In: Brake, K., Herfert, G. (eds.): Reurbanisierung. VS Verlag, Wiesbaden, pp. 323-343.

HEINKERS, H. (2004): Boomtown Leipzig: Anspruch und Wirklichkeit. Faber \& Faber, Leipzig, $287 \mathrm{pp}$.

HENCKEL, D., GRABOW, B., HOLBACH, B., USBECK, H., NIEMANN, H., eds. (1993): Entwicklungschancen deutscher Städte - die Folgen der Vereinigung. Kohlhammer, Stuttgart, $567 \mathrm{pp}$.

HERFERT, G. RÖHL, D. (2001): Leipzig - Region zwischen Boom und Leerstand. In: Brake, K., Dangschat, J.S., Herfert, G. (eds.): Suburbanisierung in Deutschland. Aktuelle Tendenzen. Leske + Budrich, Opladen, pp. 151-162.

HOLM, A. (2012): Paradoxien und Begleiterscheinungen der Reurbanisierung. In: Brake, K., Herfert, G. (eds.): Reurbanisierung. VS Verlag, Wiesbaden, pp. 239-256.

KÄHRIK, A. (2002): Changing social divisions in the housing market of Tallinn, Estonia. Housing, Theory and Society, 19, No. 1, pp. 48-56. 
KEENAN, P., LOWE, S., SPENCER, S. (1999): Housing abandonment in inner cities - the politics of low demand for housing. Housing Studies, 14, No. 5, pp. 703-716.

MARCINCZAK, S., GENTILE, M., STEPNIAK, M. (2013): Paradoxes of (post)socialist segregation: metropolitan sociospatial divisions under socialism and after in Poland. Urban Geography, 34, No. 3, pp. 327-352, http://dx.doi.org/10.1080/02723638.2013.778667.

MARCINCZAK, S., MUSTERD, S., STEPNIAK, M. (2011): Where the grass is greener: Social segregation in three major Polish cities at the beginning of the $21^{\text {st }}$ century. European Urban and Regional Studies, DOI: 10.1177/0969776411428496, pp. 1-21.

MARCIŃCZAK, S., SAGAN, I. (2010): The Socio-spatial restructuring of Łódź, Poland. Urban Studies 48, No. 9, pp. 1789-1809.

MARCUSE, P. (1986): Abandonment, gentrification and displacement: the linkages in New York City. In: Smith, N., Williams, P. (eds): Gentrification of the City, Unwin Hyman, London, pp. 153-177.

NUISSL, H., RINK, D. (2005): The "production" of urban sprawl in eastern Germany as a phenomenon of post-socialist transformation. Cities, 22, pp. 123-134.

PARYSEK, J.J. (2005): Development of polish towns and cities and factors affecting this process at the turn of the century. Geographia Polonica, 78, pp. 99-115.

POWER, A., PLOEGER, J., WINKLER, A. (2011): Phoenix cities. The Fall and Rise of Great Industrial Cities. Bristol, Policy Press, $412 \mathrm{pp}$.

RINK, D. (2015): Zwischen Leerstand und Bauboom: Gentrification in Leipzig. In: Eckardt, F., Seyfarth, R., Werner, F. (eds.): Leipzig. Die neue urbane Ordnung der unsichtbaren Stadt, Unrast Verlag, Münster, pp. 88-107.

RINK, D., HAASE, A., BERNT, M., ARNDT, T., LUDWIG, J. (2011): Urban shrinkage in Leipzig, Germany. Research Report, EU 7 FP Project Shrink Smart (contract No. 225193), WP2. UFZ report 01/2011, Helmholtz Centre for Environmental Research - UFZ, Leipzig.

RINK, D., HAASE, A., GROSSMANN, K., COUCH, C., COCKS, M. (2012): From long-term shrinkage to re-growth? A comparative study of urban development trajectories of Liverpool and Leipzig. Built Environment 38, No. 2, pp. 162-178.

RUOPPILA, S. (2006): Residential differentiation, housing policy and urban planning in the transformation from state socialism to a market economy. The case of Tallinn. Helsinkie University of Technology, Centre for Urban and Regional Studies (Centre for Urban and Regional Studies Publications, A 33), Helsinki, http://ethesis.helsinki.fi/julkaisut/val/ sospo/vk/ruoppila/resident.pdf, 64 pp. (28. 1. 2010).

SPIEKER, R. (2005): Schrumpfende Märkte in der Wohnungswirtschaft. V\&R unipress, Göttingen, $207 \mathrm{pp}$.

Stadt Leipzig, Amt für Statistik und Wahlen (2012): Ortsteilkatalog 2012.

Stadt Leipzig, Amt für Statistik und Wahlen (2013): Statistischer Quartalsbericht 4/2013.

STANDL, H., KRUPICKAITE, D. (2004): Gentrification in Vilnius (Lithuania) - the example of Užupis. Europa Regional, 12, No. 1, pp. 42-51.

STEINFÜHRER, A. (2004): Wohnstandortentscheidungen und städtische Transformation. Vergleichende Fallstudien in Ostdeutschland und Tschechien. VS Verlag für Sozialwissenschaften, Wiesbaden, $336 \mathrm{pp}$.

STEINFÜHRER, A., HAASE, A. (2009): Flexible-inflexible: Socio-demographic, spatial and temporal dimensions of flat sharing in Leipzig (Germany). GeoJournal, 74, No. 6, pp. 567-587.

STEINFÜHRER, A., HAASE, A., KABISCH, S. (2009): Reurbanisierungsprozesse zwischen Planung und Realität. Das Beispiel Leipzig. In: Kühn, M., Liebmann, H. (eds.): Regenerierung der Städte. Strategien der Politik und Planung im Schrumpfungskontext. VS Verlag, Wiesbaden, pp. 176-194.

SÝKORA, L. (2009): New socio-spatial formations: Places of residential segregation and separation in Czechia. Tijdschrift voor Economische en Sociale Geografie, 100, No. 4, s. 417-435.

TOPFSTEDT, T. (1990): Leipzig gestern - und heute? in: Initiativgruppe Volksbaukonferenz (ed.): Tagungsergebnisse der 1. Leipziger Volksbaukonferenz. Leipzig, pp. 25-29.

WIEST, K. (2005): Reurbanisierung als Mainstream der ostdeutschen Stadtentwicklung? Raumplanung 123, pp. 237-242. 
WIEST, K., HILL, A. (2004): Sanfte Gentrifizierung, Studentifizierung und Inseln ethnischer Konzentration in ostdeutschen Innenstadtrandgebieten? Das Beispiel Leipzig. Raumforschung und Raumordnung 62, pp. 361-374.

\section{Shrnutí}

\section{TRANSFORMACE VNITŘNÍHO MĚSTA MEZI REURBANIZACÍ A GENTRIFIKACÍ: LIPSKO, VÝCHODNÍ NĚMECKO}

Od počátku post-socialistické transformace prošlo v krátkém časovém období východoněmecké město Lipsko celou řadou zásadních změn. Tyto změny se nejdynamičtěji projevily v jeho vnitřním městě: zatímco $\mathrm{v}$ devadesátých letech vnitřní město postihl výrazný úbytek obyvatelstva a vyprazdňování nemovitostí, nové tisíciletí naopak přineslo revitalizaci a zatraktivnění mnoha městských čtvrtí. Ve stále rostoucím počtu čtvrtí jsou od té doby zřejmé projevy procesu reurbanizace a v některých $\mathrm{z}$ nich také gentrifikace. Tento vývoj proměnil vzorec socio-prostorové diferenciace v celém městě i jeho částech.

Studie zkoumá vývoj vnitřního města Lipska po roce 1990. Záměrem článku je ukázat, jak dva rozdílné koncepty - reurbanizace a gentrifikace - mohou tento vývoj vysvětlit. Zvláštní pozornost je věnována významu specifické situace na trhu s bydlením v Lipsku, která je charakteristická dlouhodobým přebytkem bytů a smrštováním.

Vzhledem ke čtyřicetiletému období státního socializmu, kterým město prošlo mezi lety 1949 a 1989, je v článku o Lipsku uvažováno jako o post-socialistickém městě. Dědictví tohoto období je ve městě stále zřejmé, přestože již došlo k zásadní proměně všech městských struktur a politik. Na rozdíl od ostatních post-socialistických měst je se však Lipsko vyrovnává s následky německého znovusjednocení (stejně jako ostatní východoněmecká města). I proto představuje Lipsko zajímavý případ pro studium post-socialistických měst, nebot' lze na něm pozorovat vývoj post-socialistického městského prostoru v kontextu radikálních transformačních změn působících souběžně s integrací do jiných struktur.

Na základě naší analýzy jsme dospěli k těmto závěrům: gentrifikace a reurbanizace jsou podle našeho názoru dva kvalitativně odlišné koncepty, které nemají jednoduše popsatelný kauzální ani chronologický vztah. Gentrifikace není logickým důsledkem reurbanizace a není na ní automaticky ani nutně navázána. V případě Lipska je souhra mezi gentrifikací a reurbanizací do značné míry způsobena smrštováním města a přebytku bytů na trhu. $\mathrm{V}$ době výrazných populačních ztrát $\mathrm{v}$ devadesátých letech byla gentrifikace tažena pouze nabídkou a zůstala „rozdělená“ v důsledku nedostatečné poptávky. Naopak v následujícím desetiletí zažilo město dynamickou reurbanizaci, když do něj přišly nejrůznější skupiny obyvatel, a proces gentrifikace byl „mírný“ právě kvůli přebytku (neobydlených) bytů a nízké intenzitě vytlačování původních obyvatel ze čtvrtí vnitřního města. Zmiňované dekády tak nemohou být považovány za příklad dvojitého cyklu invaze - nahrazení. Pouze v několika posledních letech lze pozorovat některé procesy podobné známému cyklickému modelu. Rozdíl mezi dvěma fázemi procesu lze vysvětlit jednak měnícími se vztahy mezi nabídkou a poptávkou na trhu s bydlením, dále rozdílnými investičními cykly z hlediska jejich zdroje, způsobu a délky působení. Lipsko je tak významným případem nestandardního vývoje gentrifikace. Zároveň lze jeho příkladu poukázat na to, že explanační přístup, který využívá více konceptů, může poskytnout ucelený obraz o propojení a interakci různých vývojových trajektorí. Studie také pomohla zdůraznit význam kontextuálních faktorů pro porozumění procesům gentrifikace a reurbanizace, jejich vzniku, vývoji a proměně, stejně jako faktorům které je ovlivňují.

Díky svým specifickým podmínkám je Lipsko možné srovnávat s dalšími post-socialistickými městy nebo západoevropskými městy jen v omezené míře. Zatímco přebytky na trhu s bydlením a problém smrštování lze pozorovat i v případě jiných měst, až kombinace s post-socialistickým kontextem činí z Lipska tak pozoruhodný př́ípad pro studium. I přes tyto velmi specifické podmínky vývoje může analýza transformace vnitřního města Lipska poskytnout cenné informace obecnější povahy: na jeho příkladu můžeme usuzovat na důsledky dlouhodobého převisu nabídky bytů a jeho dopadu na trh s bydlením a vývoj obytných čtvrtí; dále na prríležitosti a rizika, které tento vývoj přináší. Na tomto případu lze také 
pozorovat dopady převisu nabídky bytů na probíhající sociálně prostorové procesy. S ohledem na $\mathrm{v}$ současnosti probíhající demografické změny, ke kterým patří zejména stárnutí populace a zesílení a diverzifikace (mezinárodní) migrace, lze očekávat, že mnoho evropských i světových měst čeká proměnlivý vývoj od jejich růstu, přes smrštování až k obnovení růstu. Lipsko tak představuje př́klad toho, jak může takový vývoj dopadat na různé lokality a odlišné segmenty bytového trhu, či jak ovlivňuje (pozitivně či negativně) různé skupiny obyvatel. Ekonomická krize a nedávný kolaps na trhu s nemovitostmi v některých evropských zemích (např. ve Španělsku, Irsku, Recku nebo Slovinsku) způsobil převis nabídky bytů, který výrazně ovlivní trhy s bydlením v těchto zemích a zřejmě také residenční mobilitu a socio-prostorovou diferenciaci. I v těchto případech možná bude možné využít zkušenosti získané při studiu vývoje města Lipska. V závěru článku se autoři dále věnují konceptům jako je gentrifikace a re-urbanizace a zejména jejich provázanostem a vzájemným vlivům. Specifický příklad města Lipska může $\mathrm{k}$ debatě přispět odlišným pohledem na současné interpretační rámce transformace vnitřních měst.

Obr. 1 - Vývoj počtu obyvatel v Lipsku v letech 1933-2012.

Obr. 2 - Vymezení vnitřního města v Lipsku.

Obr. 3 - Změna v počtu obyvatel v Lipsku 1992-1998 podle městských částí (v procentech).

Obr. 4 - Rozpadající se domy ve vnitřním městě.

Obr. 5 - Změna v počtu obyvatel Lipsku 1999-2009 podle městských částí (v procentech).

Obr. 6 - Koncentrace obyvatel ve věku 20-30 let podle městských částí v letech 1992-2009.

Obr. 7 - Změna v počtu obyvatel Lipsku 2009-2013 podle městských částí (v procentech).

Obr. 8 - Luxusní část bytového trhu.

Obr. 9 - Nová výstavba bytových domů.

Obr. 10 - Lokalizace dražšího bydlení v Lipsku 2014: renovace a novostavby. V legendě shora: nová výstavba; starší výstavba, kombinace renovací a nové výstavby, jiné, městské části, hranice města.

Authors' affiliation: Helmholtz Centre for Environmental Research, Department of Urban and Environmental Sociology, Leipzig, Germany; e-mail annegret.haase@ufz.de.

Initial submission, 2 July 2014; final acceptance 18 April 2015.

\section{Please cite this article as:}

HAASE, A., RINK, D. (2015): Inner-city transformation between reurbanization and gentrification: Leipzig, eastern Germany. Geografie, 120, No. 2, pp. 226-250. 